\title{
INNOVATION SAFETY MANAGEMENT BY SHAPING THE LAW ON NON-PRACTISING ENTITIES (PATENT TROLLS) IN THE USA AND EU
}

doi: $\quad 10.2478 /$ czoto-2019-0021

Date of submission of the article to the Editor: 02/11/2018

Date of acceptance of the article by the Editor: 19/02/2019

Tomasz Odzimek ${ }^{1}$ - orcid id: 0000-0002-2497-2811

${ }^{1}$ Czestochowa University of Technology, Poland, tomasz.odzimek@wz.pcz.pl

\begin{abstract}
In a knowledge-based economy, innovation resulting from $R$ \& $D$ activities and subsequent management of their legal safety are of particular importance. Incorrect patent law can lead to abuse in the area of innovation security on a large scale through the activities of the NPE organization (patent trolls). This phenomenon is particularly noticeable in the US while in the EU it is at a negligible level.

The aim of the article is to demonstrate and prove by using comparative literature and documents analysis of US and EU, that inappropriate law leads to violations of innovation safety through the unhampered activity of patent trolls, while a change of the law to more restrictive law is a right step to reduce the patent trolling. On the other hand, the author proves that in an area with a less liberal definition of patentability, there are no many violations of innovation safety through patent trolling.
\end{abstract}

Key words: management of legal safety of innovation, patent trolling

\section{INTRODUCTION}

The contemporary economic system in developed countries and rapidly developing countries is termed the knowledge-based economy. This new model begann when Intangible (nonphysical) assets had, after all quite literally replaced conventional business economies that had for hundreds of years evolved around the production and utilization of tangible (physical) assets. This economic transformation begann in the mid to late 1990s and started to influence business decision makers, management teams and bord globally to rethink their business strategies to include identifying and profitably exploiting theit intangible assets (Moberly, 2014). The knowledge-based economy represents a modern and the most recent management method and encourages innovativeness in the economy. Therefore, the activity of enterprises is focused primarily on developing innovations. Innovations were defined in the Oslo Manual of 2005 developed by the Organization for Economic Cooperation and Development (OECD) and Eurostat regarding the principles of collecting and interpretation of innovation data.

The contemporary global economy is mainly viewed as associated with the dynamic development of high technology sectors that use the most recent scientific 
achievements on a large scale. A substantial number of high-tech sectors present in the industry is one of the characteristics of highly developed countries (Mizgalska and Wsciubak, 2009). High-tech sectors are more and more often driven by knowledge creation processes and transfer of knowledge from the world of science to business. Nowadays, top-level innovations are increasingly developed through cooperation of many organizations within networks, including enterprises, R\&D institutions, and support institutions such as innovation centres (Odzimek, 2015).

The world of technological innovations is often supported by huge finance. World corporations spend millions and sometimes even billions of dollars to develop innovative solutions that help them achieve better position in the market and strengthen their competitiveness. Another motivation is to eliminate market competitors, which shows how high the power of innovativeness is and how important it can be as a tool for market expansion. However, in order for the competition in the global market to occur in accordance with the legal, institutional and administrative rules of modern world, it is necessary to ensure safetty of innovations and transfer of these innovations. This can be achieved through effective management of their safety, which can be considered from different standpoints. One of them is safety with respect to legal protection against the unauthorized use of other persons or entities of business trading. The business trading practice shows that the lack of sufficient legal protection of inventions reduces innovation safety, disturbs fair competition and leads to the deactivation of innovativeness. The lack of sufficient safety in business trading results in its abuse by dishonest business entities which exploit this situation, guided by the desire to make huge profits at the expense of other business entities.

Unfortunately, inadequate legal protection of innovations is accompanied by the negative trends consisting in running business while utilizing weaknesses of legal protection law of industrial property by entities referred to as patent trolls.

\section{PATENT TROLLING}

The phenomenon of patent trolling has been observed since recently and is a new form of abuse of patent rights. Patent trolling has been defined as 'the practice of purchasing and maintaining patents and hiding them in the company's portfolio until the market for a given technology is developed and the patents are necessary for the survival in the market. If such conditions are met, the patentee requests paying license fees or sues the company, often as part of a protection procedure that is threatening them in such cases." (Pohlmann and Opitz, 2013). Patent trolling is particularly dangerous when the object of a patent owned by a trolling enterprise becomes a standard in the specific market, and, without the patents, the enterprises are unable to function in this market (Kattan and Wood, 2013).

A new organizational form related to such activities, termed a non-practising entity (NPE) continues to be the main cause of legal disputes related to patents. NPEs collect patents not for the production of commercial products, but for the purpose of claiming license fees and/or judicial violations. NPEs activities increase the costs of innovations by exploiting the fact that costs of legal cases, along with the risks of imperfect courts, can help NPEs derive benefits, even if no violation actually occurred or the patents fail to survive the validity test). Furthermore, the activities of these organizations may increase the costs of production associated with the implementation of innovations and the loss of credibility concerning their actual intellectual property (Lauren et al., 2014). 
The activity of patent trolls impacts on the safety of innovations in the economy to a significant extent and concerns the issue of managing the safety of these innovations or, in other words, safety of business trading. The activity of patent trolls contributes to the abuse of fair market competition and leads to the reduced safety of innovation in business transactions. The activity of NPEs, which is inconsistent with the rules of fair business on the one hand, and consistent with law on the other, leads to a significant reduction in inventiveness and business activity of entrepreneurs who want to introduce innovations to the market. It is therefore reasonable to ask whether the development of innovation law can enable or counteract the activities of patent trolls and thus take care of innovation safety and innovation transfer.

So far, this phenomenon has been observed mainly in the United States. According to experts, this is due to the fact that relevant legal regulations do not keep pace with the dynamically growing sectors such as IT. Another cause is regulations that allow for e.g. patenting software. These regulations result from the historical approach of theoreticians of law and economics from the 1960s, who generally believed that economics explains everything. For tchem market is self-correcting and private economic power is less problematic than government intervention (Derclaye and Taylor 2015).

It is also important that the principle of reimbursement of litigation costs by the losing party is not used in the USA, which is why patent trolling is more profitable than in Europe. In recent years, the trolling threats have also been addressed in the European Union, and the first cases related to this practice are pending before the Court of Justice. Furthermore, in recent years, the European Commission started several anti-trust proceedings against companies that could abuse their dominant position by using patent trolling (Malaga, 2016).

It is worth examining the sources of these problems, i.e. the legal situation concerning patenting of innovations on both continents in order to emphasize the differences in the understanding of patent protection aimed at strengthening innovation safety.

In the United States, the respective patent office is the United States Patent And Trademark Office (USPTO). According to the patent law stipulated by the American Inventors Protection Act of 1999 (AIPA) any person who "invents or discovers any new and useful process, machine, manufacture, or composition of matter, or any new and useful improvement thereof, may obtain a patent," subject to the conditions and requirements of the law (American Inventors, 1999). The word "process" is defined by law as a process, act, or method, and primarily includes industrial or technical processes. The term "machine" used in the statute needs no explanation. The term "manufacture" refers to articles that are made, and includes all manufactured articles. The term "composition of matter" relates to chemical compositions and may include mixtures of ingredients as well as new chemical compounds. These classes of subject matter taken together include practically everything that is made by man and the processes for making the products (United States, 2015).

Therefore, it has long been recognized in the USA that computer software may be subject to patent protection. The US legislation does not require that the patented invention produces physical effects. Therefore, it is allowed to patent software as such, and to patent business methods. The first such patent was granted in 1968 for a data search software. In recent years, a change in the approach to patenting computer software can be seen in the judicial decisions of the US Supreme Court. It 
occurred due to the ruling on the case of Alice Corp. v. CLS Bank w czerwcu 2014 r. (134 S. Ct. 2347, 19 June 2014). In this ruling, the Supreme Court indicated that if a computer software is based on an abstract idea, e.g. it concerns the method of calculating the financial risk using a known mathematical formula, several additional premises should be fulfilled in order for the patent to be granted protection.

In Europe, including Poland, the situation seems to be more unequivocal. The European Patent Office (EPO) performs the tasks related to patenting under the European Patent Convention Article 52. The Convention prohibits patenting software 'as such'. According to the Convention:

(1) European patents are granted for inventions that are new and involve an inventive step,

(2) The following are not regarded as inventions with the meaning of the paragraph 1 :

(a) discoveries, scientific theories and mathematical methods;

(b) aesthetic creations;

(c) schemes, rules and methods for performing mental acts, playing games or doing business, and programs for computers (European Patent Convention, 1973).

The EPO began to recognize that it is possible to patent software with technical outcomes differing from those of other programs. Furthermore, it started to be disputed whether software that is part of a device can be patented. In 2008, a court in the United Kingdom decided that if the legislation allows patenting an innovative method to perform a task, it actually also allows patenting a software used to implement this method. More specifically, European law does not preclude the possibility of patenting software in advance, but such acts are by principle unacceptable, and in practice, substantially less possible than in the USA.

With knowledge about the differences in the legislature in the USA and the EU, the question should be asked whether they actually impact on differences related to infringement of patent rights as part of patent trolling and, therefore, on innovation safety. In addition, it should be verified whether appropriate law-making reduces the negative activity of patent trolls who decrease the innovation market safety.

For this purpose, the author performed the literature analysis in order to demonstrate that the appropriate formulation of legislation on the legal protection of innovations has an effect on the level of safety of both innovations and their transfer. The hypothesis was assumed that excessively liberal patentability law contributes to NPEs' more frequent participation in litigations that are the main source of their revenues. The second assumption was that innovation safety management can be implemented through appropriate shaping of patent law.

\section{METHODOLOGY OF RESEARCH}

The focus of the analysis of the literature and documents were the differences between the USA and the EU in the involvement of NPEs (patent trolls) in court disputes concerning patent innovations. Furthermore, the study analysed the effect of the current law on the activity of patent trolls in both areas and whether changes in the law into more stringent regulations impact on the decrease in their activity.

The research technique was the analysis of the related sector literature, court case law, and comparative analysis of statistical data derived from the US and EU patent offices concerning litigations. The study was conducted in the period of October and November 2018. 


\section{RESULTS}

The literature review showed that:

- in the USA, legislation allows for greater exploitation of the situation in the market of inventions and patents compared to the EU,

- two events contributed to the change in the trend of the abuse of inventions and patents by NPEs.

The first event was the case of the company Myriad Genetics, which, in the 1990s, patented BRCA1 and BRCA2 genes (with their mutations potentially contributing to prevalence of breast and ovarian cancers). If an entity wanted to examine these genes, they were allowed to do so only for a fee by using a special test developed by Myriad Genetics. This situation was unchanged until 2013, when the US Supreme Court announced the ruling invalidating these patents and claiming that they go beyond the scope of patentability.

The second event was the change of the law in 2015, which confirmed the ruling of the US Supreme Court and subsequent judicial decisions regarding patents. The abolishment of Rule 84 of the Federal Rules of Civil Procedure and its use of Form 18 , which simplified the process of bringing a suit for direct patent infringement (especially useful for smaller companies and solo inventors). With this change, the default pleading standard for patents will be the heightened plausibility standards as set forth in Bell Atlantic Corp. v. Twombly and Ashcroft v. Iqbal.

In order to demonstrate that the legal situation affects the scale of patent abuse by NPEs, the number of these organizations in the USA and EU in 2010-2017 was analysed, and comparative studies were conducted in order to confirm the hypothesis that the legal situation has an effect on the level of patent innovation safety.

The number of court litigations sued by NPEs was compared between the USA and the EU. The study found that there is a very big difference in the number of such patent disputes, to the disadvantage of the USA (see Figure 1). There were substantially more such cases in the United States compared to the area of the European Community. This was ca. a several-dozen times predominance of such cases. It should also be emphasized that the highest level of disputes was achieved in 2013 (over 4,400), while in Europe, this number was only 90 in the respective period. After 2013, the number steadily declined to reach the level of 2,750 in the USA in 2017, whereas in the EU, it increased to 173 legal disputes.

Figure 1. reveals two observations. Firstly, the assumption that the changes concerning judicial decisions in 2013 and changes in the law in 2015 contributed to the tightening of the patentability criteria and, consequently, to the reduction of court disputes involving so-called patent trolls was confirmed. Secondly, the less liberal law regarding the European Patent prevents the freedom of activities of patent trolls, who mainly strive for litigations in order to obtain compensations. In the EU, there are several dozen times fewer such cases compared to those observed in US commercial courts. 


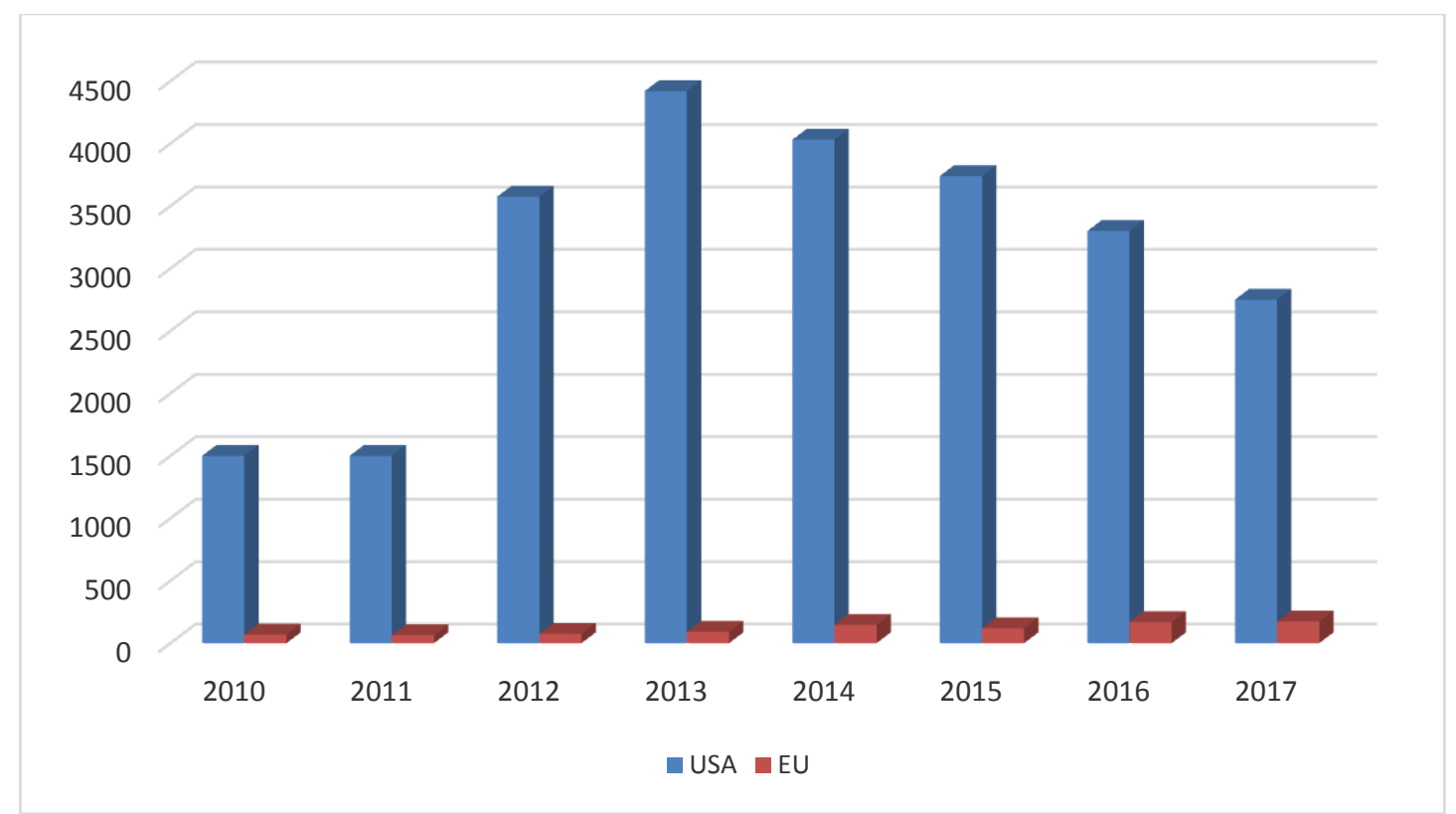

Fig.1. Number of court disputes involving NPEs

Source: author's own study based on: UnifiedPatents, 2016 Annual Patent Dispute Report, https://unifiedpatents.squarespace.com/news/?offset=1483492841350

Council of Economic Advisers Issue Brief, The Patent Litigation Landscape: Recent Research And Developments, 2016,

Darts-ip, NPE Litigation In The European Union, Fact and Figures, 2018,

PricewaterhouseCoopers, 2017 Patent Litigation Study Change on the horizon?, 2017.

Furthermore, it is worth asking whether the percentage of NPEs in the number of patent litigation cases is also greater in the USA. The research showed a substantially high difference to the disadvantage of the United States (chart 2). While this percentage reached almost 6\% in 2010-2017 in the European Union (with $4 \%$ on average), this was $65 \%$ in the peak year (2013) in the United States, with average of ca. $50 \%$. Figure 2 shows clearly that substantially more (even a dozen times more) cases involving NPEs in the total number of patent litigation cases were found in the USA compared to the EU.

The next analysis of statistical data confirmed the hypothesis that with the legal status which was unfavourable from the standpoint of innovation safety, the possibilities of infringing this safety by entities such as patent trolls are greater. The analysis also confirmed that the change of the excessively liberal patent law to a more rigorous one contributes to stopping activities performed by patent trolls, as it was the case in the USA. A worrying trend for the growing phenomenon of patent trolling can be observed in Europe, which, however, remains much lower than in the USA. The reason for this growth in Europe is, as described above, that the law does not preclude the possibility of patenting software, although it is essentially unacceptable.

The next diagram also demonstrates the validity of the adopted hypothesis (Figure 3 ). It contains the statistical survey results concerning the number of patent litigation cases in total for a specific research area. It can be assumed that in 2010-2017, the total number of patent disputes in the EU was by ca. $60 \%$ lower than in the USA. Furthermore, it should be noted that only in 2011, there were a few percent advantage of these disputes in the USA compared to the EU, whereas in 2015 , the advantage reached ca. $140 \%$. 


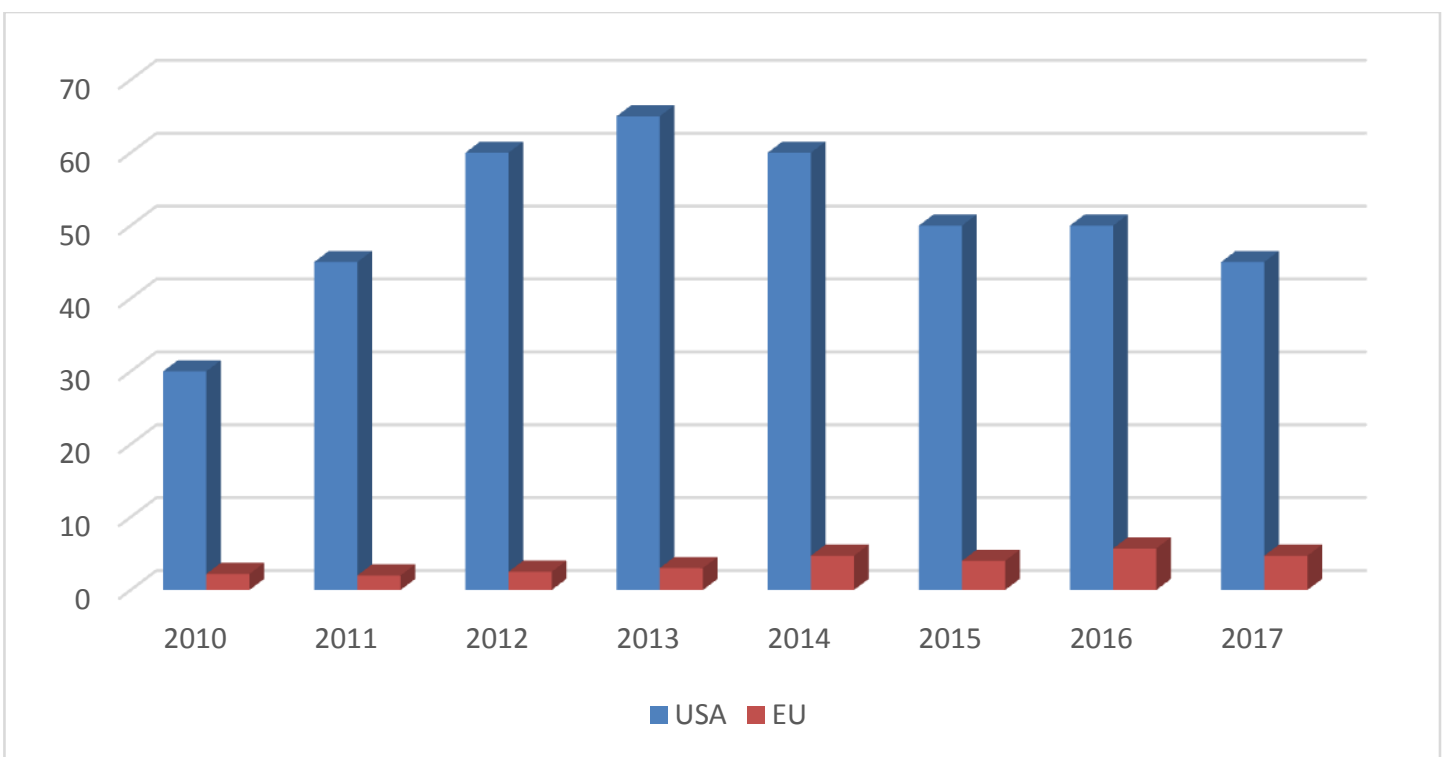

Fig. 2. Percentage of NPEs in the number of patent litigations in $\%$

Source: author's own study based on: UnifiedPatents, 2016 Annual Patent Dispute Report, https://unifiedpatents.squarespace.com/news/?offset=1483492841350,

Council of Economic Advisers Issue Brief, The Patent Litigation Landscape: Recent Research And Developments, 2016,

Darts-ip, NPE Litigation In The European Union, Fact and Figures, 2018,

PricewaterhouseCoopers, 2017 Patent Litigation Study Change on the horizon?, 2017,

Eueropean Patent Office EPO, Annual Report 2017 - Five-year overview, Annual Report 2013

- Five year overview.

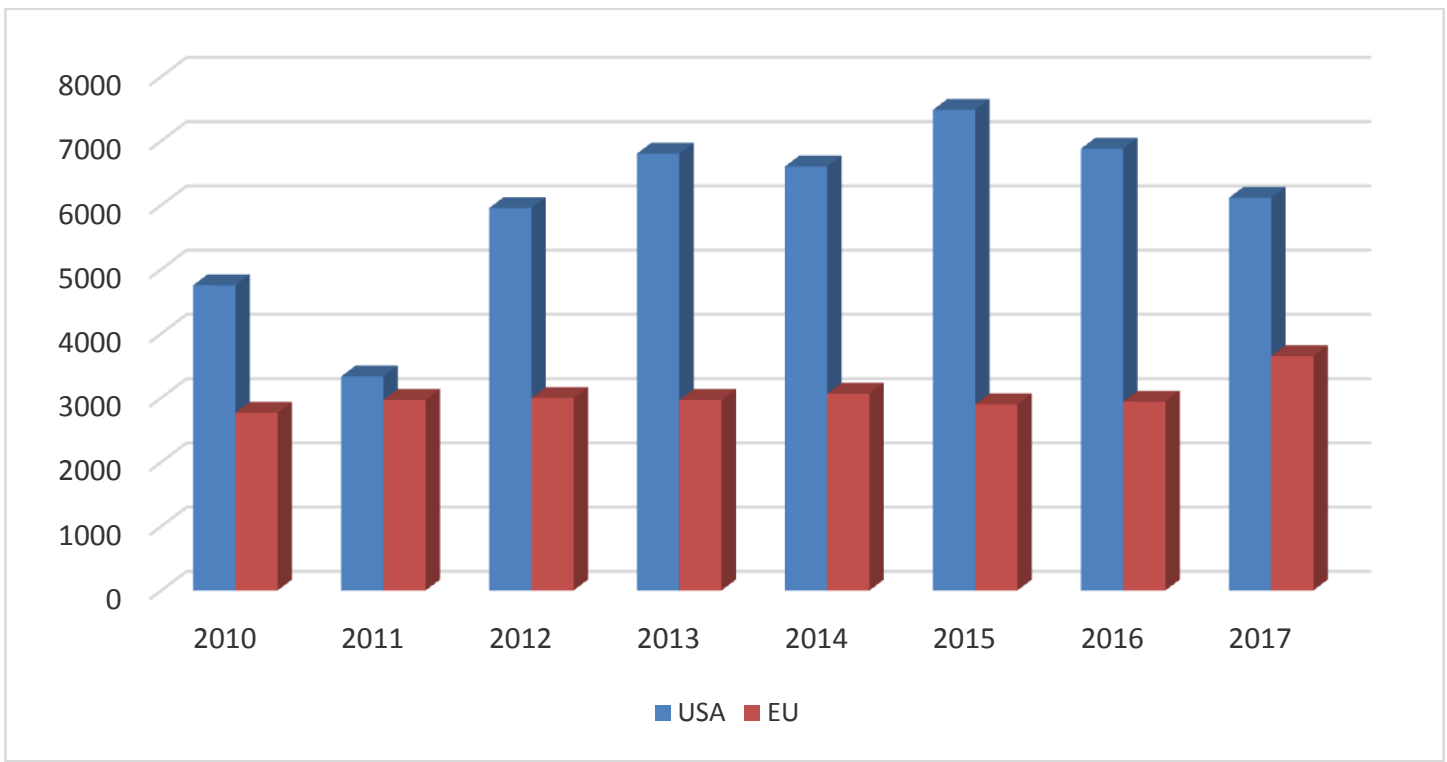

Fig. 3. The number of patent litigation cases

Source: author's own study based on: UnifiedPatents, 2016 Annual Patent Dispute Report, https://unifiedpatents.squarespace.com/news/?offset=1483492841350,

Council of Economic Advisers Issue Brief, The Patent Litigation Landscape: Recent Research And Developments, 2016,

Darts-ip, NPE Litigation In The European Union, Fact and Figures, 2018,

PricewaterhouseCoopers, 2017 Patent Litigation Study Change on the horizon?, 2017,

Eueropean Patent Office EPO, Annual Report 2017 - Five-year overview, Annual Report 2013

- Five year overview. 
This led to the confirmation of the following pattern. While the number of NPEs taking part in court disputes and the percentage of NPEs in patent litigations is even several times higher in the case of the USA compared to the EU, the advantage of the USA in the total number of patent litigations was only around $60 \%$. This shows the degree to which the phenomenon of patent trolling occurs, which is caused, as demonstrated in the study, by an inadequate legal status regarding patentability.

\section{CONCLUSION}

The analysis of literature and documents revealed that the assumed hypotheses were correct. Excessively liberal patent law in the USA has led to enormous abuse of these rights through actions taken by NPEs, also termed patent trolls. It was only the change in judicial decisions and the change in law that partially reduced this problem in the USA, while in the EU, such changes were not necessary due to the more restrictive patent law.

The assumption was also made that the innovation management can be implemented through effective shaping of patent law. The relevant law prevents harmful activities of the NPEs that reduce the innovation safety while the incorrect right contributes to such activities. This means that the management of innovation safety can consist in activities in the field of law, and effective law-making in order to prevent abuse by NPEs.

The importance of the scale of abuse of laws protecting innovations to innovation safety is demonstrated by well-known examples such as the company Eolas Technologies, which, due to patent litigations, forced Microsoft to pay the amount of 521 million dollars. For the same reason, Apple was required at the beginning of 2016 to pay 625.6 million dollars for the violation of VirnetX's patents. Apple was accused of unlawful use of four solutions and, in each case, the infringement of protection was adjudicated (Reuters, 2018). Furthermore, a study conducted by the scientists at Boston University indicated that only in 2011, patent trolls exposed companies in the US to direct costs amounting to 29 billion dollars. This amount included license fees and legal costs (Bessen and Meurer, 2012).

The literature analysis presented in this paper confirmed the legitimacy of the statement that the improper patent law (patentability) leads to huge losses (reaching even billions of dollars) for the companies protecting their inventions covered by patent protection. These losses result from inadequate management of innovation safety, which has a negative impact on the innovative activity of enterprises, their entrepreneurship and threatens the safety business trading. Therefore, the author postulated that the development of patent law in the European Union should remain rigorous with regard to patentability, whereas the results of the analysis suggest that the US legislation should depart from overly liberal regulations in this area, which will enhance safety of innovations and their transfer between companies from both economic areas.

\section{REFERENCES}

Bessen, J., Meurer, M. J., 2012. The direct costs from NPE's disputes. Boston University School of Law Working Paper No. 12-32, Boston, 1-2. https://papers.ssrn.com/sol3/papers.cfm?abstract_id=20912109.11.2018 
Darts-ip, 2018. NPE Litigation In The European Union. Fact and Figures.

Derclaye, E., Taylor, T., 2015, Replacing the Law and Economics Justification for Intellectual Property Rights with a Well-being Approach, European Intellectual Property Review, Volume 37 Issue 4, Sweet\&Maxwell Thompson Reuters pp.200.

Eueropean Patent Office EPO, Annual Report 2017 - Five-year overview, Annual Report 2013 - Five year overview.

Kattan, J., Wood, Ch., 2013, Standard-Essential Patents and the Problem of Hold-up, Social Science Research Network.

http://awa2014.concurrences.com/IMG/pdf/standard_essential_patent_kattanwood.pdf, 11.11.2018

Lauren Cohen, L., Gurun, U., Kominers, S.D., 2014. Patent trolls: evidence from targeted firms. Nber Working Paper Series, Working Paper 20322, Cambridge, 1. http://www.nber.org/papers/w20322, 4.11.2018

Malaga, M., 2016. Trolle na podzielonym rynku. Patent europejski o jednolitym skutku a rynek wewnętrzny I prawo konkurencji. Studia Oeconomica Posnaniensia, vol. 4, no. 6, 90-91.

Mizgajska, H., Wsciubiak, Ł., 2009. Czynniki wpływajace na aktywność innowacyjna zaawansowanych technologicznie firm produkcyjnych sektora MSP w Polsce. In: B. Kryk, K. Piech, Innowacyjność w skali makro i mikro, Instytut wiedzy i innowacji, Warszawa, 260.

Moberly, M.D., 2014. Safeguarding Intangible Assets. Butterworth-Heinemann, Elsevier, 13.

Odzimek, T., 2015. Aspekty skutecznego zarządzania kooperacją biznes-naukaadministracja w kontekście lokalnej gospodarki. Barometr regionalny 2015 ,Tom $13 \mathrm{Nr}$ 14, 105.

Pohlmann, T., Opitz, M., 2013. Typology of the Patent Troll Business. R\&D Management, vol. 43, iss. 2,103-105.

PricewaterhouseCoopers, 2017. Patent Litigation Study Change on the horizon? http://www.ipwatchdog.com/wp-content/uploads/2017/05/2017-Patent-LitigationStudy_PwC.pdf, 12.11.2018

Reuters, Apple ordered to pay $\$ 625$ million in patent dispute with VirnetX. https://www.reuters.com/article/us-virnetx-holdg-apple-idUSKCNOVC2RL,

5.11.2011

The White House, Council of Economic Advisers Issue Brief, 2016. The Patent Litigation Landscape: Recent Research And Developments. https://obamawhitehouse.archives.gov/sites/default/files/page/files/201603_paten t_litigation_issue_brief_cea.pdf 12.11.2018

United States Patent and Trademark Office, 1999. American Inventor's Protection Act of, Text of section 1000(a)(9), Division B, of Public Law 106-113, 83-182. https://www.uspto.gov/sites/default/files/web/offices/com/speeches/s1948gb1.pdf 5.11 .2018

United States Patent and Trademark Office, 2015. General information concerning patents, Virginia. https://www.uspto.gov/patents-getting-started/generalinformation-concerning-patents\#heading-2, 5.11.2018

Unified Patents, 2016. Annual Patent Dispute Report. https://unifiedpatents.squarespace.com/news/?offset=1483492841350 